\title{
Time Orientation \& Sequential Coherence as Novel Determinants of Open Innovation Performance
}

\author{
S.R. Yapa ${ }^{1}$, R. Senathiraja ${ }^{2}$, J. Poesche ${ }^{3}$ \& I. Kauranen ${ }^{4}$
}

Faculty of Management \& Finance, University of Colombo, Sri Lanka ${ }^{1 ' 2}$

Department of Industrial Engineering \& Management, Aalto University, Finland ${ }^{3,4}$

shantayapa@gmail.com'; luxumy@gmail.com²; jurgen.poesche@hotmail.com ${ }^{3}$; ilkka.kauranen@gmail.com ${ }^{4}$

Received: 21 January 2020

Accepted: 22 November 2020

\begin{abstract}
The aim of this paper is to introduce two novel variables that can explain variations of innovation performance in open innovation initiatives. Open innovation is a popular strategy among business organizations in promoting innovations. However, it does not always increase innovation performance. The reasons for the varying innovation performance in open innovation initiatives cannot be fully explained by the existing theories and variables used. This article explains how a mixed method research that has been undertaken with the objective of identifying novel determinants to explain varying innovation performance in open innovation initiatives has been progressing up to its final phase. This research follows a sequential exploration strategy as its research design. The ontology of the subject research is pragmatism. Two new determinants identified through the qualitative inquiries namely time orientation and


sequential coherence have been incorporated to a conceptual model that would be tested using data collected from software firms as the final phase of the research.

Keywords: Open Innovation, Innovation Performance, Time Orientation, Sequential Coherence

\section{Introduction}

Openness is a strategy for organizations to promote innovations (Chesbrough, 2017). It has become a trend in innovation management (Lopez \& Carvalho, 2018). Open innovation (OI) has attracted wide academic attention (Kim et al, 2015) as it encourages organizations to collaborate with external organizations in harnessing new knowledge to accelerate internal innovations and also to partner with external organizations to early commercialize innovations (Chesbrough, 2003). Through a pilot study done in 2017 using 160 managers of 114 business organizations, we found that $\mathrm{OI}$ is a popular strategy to promote innovations among organizations in Sri Lanka. Out of the selected organizations, 92 firms had some form of OI practices.

Despite its popularity as a strategy to promote innovations in organizations, there is criticism against open innovation claiming that it does not always increase innovation performance (Lee \& Shin, 2017; Yapa, et al., 2018). Cheng \& Shiu (2015) emphasize that the relationship between OI and innovation performance is not direct and increased OI may reduce innovation performance (Lauritzen \& Karafyllia, 2019; Bengtsson, et al, 2015). Scholars regularly point out the necessity to identify novel determinants to understand performance differences in open innovation initiatives. Having conducted two qualitative inquiries, the authors identified two novel variables namely time orientation and sequential coherence that can explain differences in innovation performance of open innovation initiatives. We selected the local software industry that records varying levels of innovation performance in open innovation initiatives for an empirical study as it constitutes a fertile ground. 


\section{Objectives}

The main objective of this paper is to present a conceptual model incorporating two novel determinants of open innovation performance. We first discuss the limitations of existing variables in explaining innovation performance in OI initiatives. We also discuss the theoretical background of the proposed conceptual model. Therefore, this article is best described as a concept paper that shows the progression of a mixed method research study. We justify our conceptual model in terms of its novelty and appropriateness.

\section{Literature Review}

Using the key words of open innovation and innovation performance we short listed and reviewed 218 peer reviewed journal articles in the Thomson Reuters Web of Science database and also referred 105 similar articles found in Scopus, JStore and Google Scholar. Among the mostly used theories and variables in explaining open innovation performance are absorptive capacity (Cohen \& Levinthal, 1990; De Zubielqui et al, 2016), organizational inertia (Huang et al, 2013; Godkin, 2010), dynamic capabilities (Teece et al, 1997), cognitive distance (Inaun \& Schenker-Wicki, 2012; Nooteboom et al, 2007), search depth and breadth (Laursen \& Salter, 2006; Greco et al, 2016), and ambidexterity (March, 1991; Ferrari, 2011). As open innovation goes beyond the boundaries of a focal firm (Munir et al, 2018; Powell et al, 1996), the above theories mainly focusing on internal factors fall short in explaining innovation performance differences of OI initiatives (Cheng \& Huizing, 2014; Bengtsson et al, 2015).

We understand that existing theories and variables cannot explain how an organization can select the most appropriate OI partner. Why do organizations record varying innovation performance in different OI initiatives with the same partner has not been adequately explained by researchers (Cheng \& Huizing, 2014; Bengtsson et al, 2015). It is not clear as to why some organizations succeed with some partner firms and fail with others in their OI initiatives (Von Krogh et al, 2018; Bengtsson et al, 2015). Understanding the interface between the organizations in boundary crossing innovations is important 
(Hargrave \& van de Van, 2006; Geels, 2004; Bogers et al 2017). Therefore, it is important to understand how knowledge flows across the boundaries of firms and factors that can influence the cross border knowledge flows.

Among many factors used to measure innovation performance, product and process innovations (Bianchi et al., 2015; Greco et al., 2016), contribution of new products to the revenue (Moretti \& Biancardi, 2017; Roper et al, 2013; Berchicci, 2013), revenue growth (Caputo et al, 2016; Dahlandar \& Gann, 2010), export performance (Guan \& Ma, 2003; Gkypali et al, 2018) and number of patent applications submitted (Caputo et al, 2016; Berchicci, 2013; Faems et al, 2010; Greco et al, 2016; Greco et al, 2017) are used in this study.

A key observation made in the literature review is that alignment and coordination being factors studied in inter-organizational studies have not been adequately studied in empirical studies on open innovation. The Results of a pilot study we conducted by way of interviews with key people in 5 leading software firms and 3 joint research laboratories of a leading university further justified the necessity of paying attention to alignment and coordination for the success of OI initiatives. Goal complementarity (Pullen et al, 2012; Duysters and Man, 2003; Behnam et al, 2018), resource complementarity (Haythornthwaite, 1996; Tichy et al., 1979 \& Pullen et al.,2012) and knowledge complementarity (Hopkins et al, 2011; De Mattos et al, 2018; Kogut \& Zander, 1992) can be considered as different measurable dimensions under alignment. Similarly, ease of communication, monitoring and reporting can be used in measuring coordination (Naqshbandi, 2016; Lu et al, 2017; Arashpour et al, 2017). We borrow the term convergence from the actor network theory to bundle alignment and coordination, to be tested as a factor that can influence innovation performance of open innovation initiatives. Our quest for the look out of novel determinants led us to conduct two qualitative inquiries as described in the next two sections. 


\section{Time Orientation}

We conducted a case study covering a major open innovation initiative of a subsidiary firm of a leading software company in Sri Lanka. The firm which had received its initial block funding to engage in research and innovations in emerging technologies was on the survival mode looking desperately for opportunities to commercialize several Internet of Things (IoT) projects they had in different stages of the development life cycle. They once attempted to implement a nationally important project to introduce an early warning system for potential flood victims. In this regard, the firm partnered with an international water management institute as the knowledge partner and an international insurance firm operating in Sri Lanka as the funding partner. Despite the importance of the project and the enthusiasm the three partners had on this project it came to a complete standstill. As we found through this qualitative study, time orientation differences among OI partners have the potential in explaining the innovation performance variance. Accordingly, we identified implementation time, payback period and future orientation as three dimensions of time orientation. This finding will be tested empirically to understand its generalizability.

\section{Sequential Coherence}

As the next qualitative inquiry, we selected five software firms engaged in research and innovation activities to understand factors influenced their innovation performance. The first review of data collected from the lengthy discussions and interviews with the key people in those five firms until reaching data saturation enabled the researchers to identify general categories such as strategic factors, leadership and human factors that influence knowledge flow. Creswell (1998) describes this as open coding. Goal alignment and complementarity in interests are the findings under strategic factors. Flexibility and managerial support are findings under the leadership category. The key phenomenon of interest which is boundary conditions were mostly explained through human factors. Further analysis on this described as axial coding (Creswell, 1998) revealed 
that willingness to share knowledge, preparedness for learning and level of motivation are the factors influencing the knowledge flow. we bundled them as sequential coherence to offer as a proposition.

Boundary conditions matter in innovation performance (Enkel et al, 2009; Brunswicker \& Vanhaverbeke, 2015) and sequential coherence has the potential to explain why some succeed while others fail in open innovation. The qualitative inquiry we made revealed that sequential coherence that facilitates the knowledge transfer at boundary level influence innovation performance in open innovation initiatives. Sequential coherence refers to the reciprocal result of the pushing effects induced by individuals of a teaching firm and the pulling effects induced by individuals of a learning firm that enables knowledge to flow across the boundaries of firms (Yapa et al, 2019). Sequential coherence is measured through the push and the pull effects by willingness and ability of the participants of teacher firm and the preparedness and ability of the participants from the student firm respectively (Yapa et al., 2020). A quantitative inquiry using a larger sample will enable us to generalize this finding.

\section{Empirical Test}

The two novel variables of sequential coherence and time orientation were subsequently tested using the following conceptual model in Figure 1.

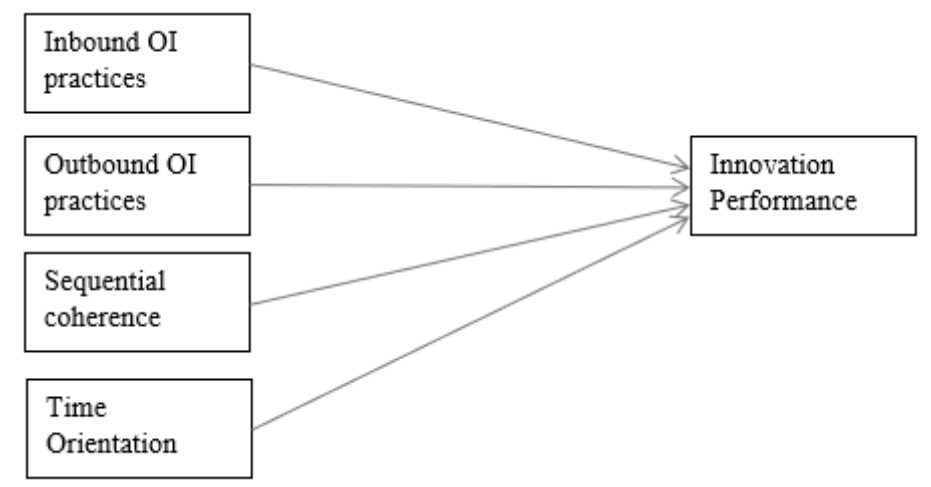

Figure 1: The Conceptual Model to Test the Two New Variables 
In this regard, we collected data from 281 practicing managers from diverse industry sectors in order to understand the ability to generalize the results. Technique used for sampling is convenience sampling which is a non-probability sampling method. We used IBM SPSS and SmartPLS software in analyzing data to ensure cross validation. Summary of the results are given below. We found that both sequential coherence and time orientation differences influence the relationship between OI practices and innovation performance in open innovation initiatives.

The $\mathrm{R}$ values recorded for the relationship each independent variable has with innovation performance were $0.714,0.651,0.738$ and 0.633 for inbound OI practices, outbound OI practices, sequential coherence and time orientation respectively. Thus, a positive relationship between the independent variables and the dependent variable has been observed. $\mathrm{R}$ square values of $0.510,0.424,0.545$ and 0.440 have been observed respectively for the above relationships. $\mathrm{P}$ values less than 0.05 were observed in all 4 hypotheses. The null hypotheses were thus rejected and a positive relationship between each independent variable and dependent variable was established. The same data set was analyzed using SmartPLS and there again positive relationships were observed in all 4 hypotheses. Figure 2 below shows the results from SmartPLS analysis.

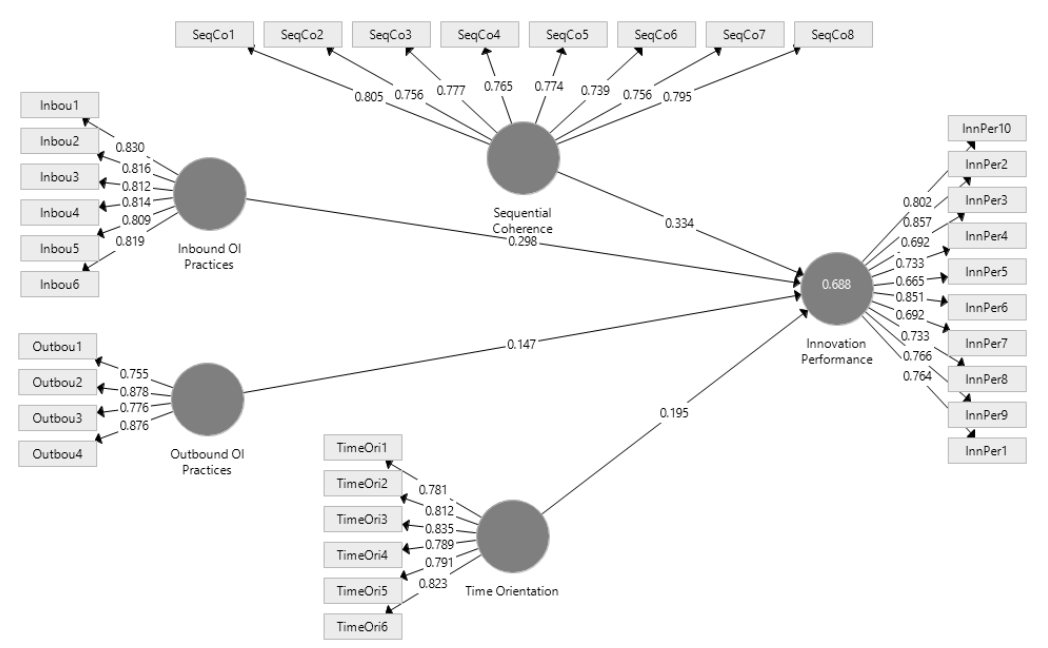

Figure 2: Results of the analysis done using SmartPLS 


\section{Conceptual Model}

Based on the results of the above quantitative study, time orientation is considered as a moderating variable and sequential coherence is considered as a mediating variable in proposing the following conceptual model in Figure 3 for the final phase of the research. According to Baron \& Kenny (1986) the moderator and mediator functions can be discussed at three levels; conceptual, strategic and statistical. Moderating variables are typically introduced when there exists an inconsistent relationship between the predictor variable and criterion variable. As discussed earlier under the literature review, OI practices and innovation performance show an inconsistent relationship. Therefore, we argue that convergence and time orientation can be introduced as moderating variables in the proposed conceptual model for the final phase of the research. A stronger relationship was observed between the predictor variable of sequential coherence and criterion variable namely innovation performance in the quantitative inquiry. Therefore, we consider sequential coherence as a mediating variable in the proposed conceptual model. This complies with the arguments of Baron \& Kenny (1986) in selecting mediating variables.

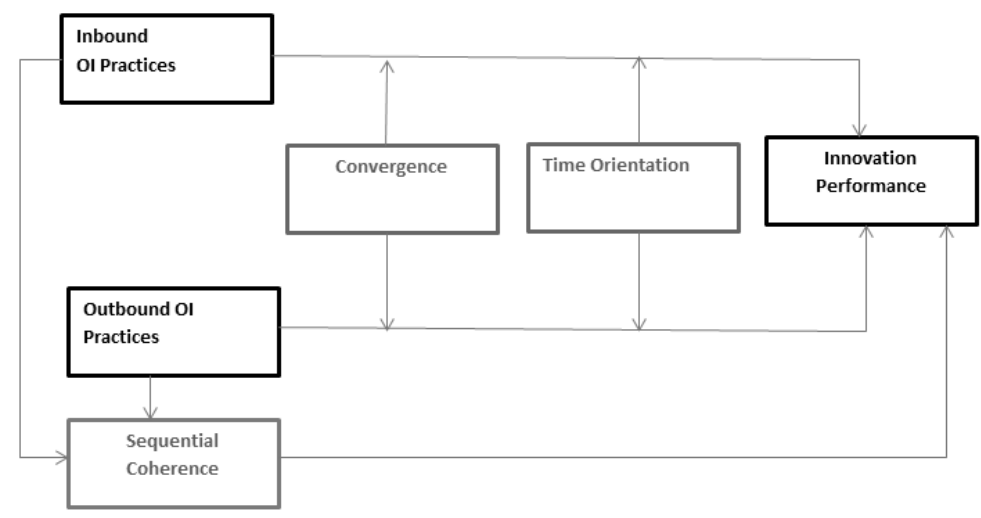

\section{Figure 3: The Conceptual Model}

The proposed conceptual model draws insights from several theories. The relationship between time orientation and innovation performance can be explained by the transaction cost economics 
theory or TCE (Williamson, 1975). TCE suggests that economic efficiency can be achieved by optimizing organization structure through minimizing exchange costs in respect of monitoring, controlling and managing transactions. Similarly, the relationship between sequential coherence and innovation performance can be justified using the dynamic capability framework or DCF (Teece, 1997) and the transaction cost economics theory. DCF focuses on the ability of an organization to orchestrate and reconfigure externally sourced competences and leverage them with internal competences swiftly. As discussed earlier, inter-organizational convergence has two dimensions identified namely alignment and coordination. The agency theory (Arrow,1971; Eisenhardt, 1989) and the transaction cost economics theory (Williamson, 1975) can be used to understand the relationship these two variables have with innovation performance.

\section{Discussion \& Implications}

Managers and academics lack a proper understanding of the mechanisms involving the boundaries of the innovation process (Enkel et al, 2009). Brunswicker \& Vanhaverbeke (2015) suggest that research on open innovation should investigate the interrelation between boundary conditions and a firm's nature of openness. OI is extensively used by organizations to promote innovations. Although, some succeed with increased innovation performance, some fail in their OI initiatives. Findings from our research will enable practicing managers to improve innovation performance of their organizations. Sequential coherence demands managers to scan the boundaries of the organization where cross-border knowledge flow happens and take appropriate corrective actions. Similarly, time orientation suggests managers to be mindful about the differences in time orientation among OI partners which can hinder or halt innovation performance. In addition to these primary findings through which we offer two novel determinants to open innovation literature, we also test convergence by way of alignment and coordination among OI 
partners which can bring useful insights to researchers and practicing managers.

\section{Acknowledgement}

A paper on Sequential Coherence was presented at the International Conference on Business Research (ICBR 2019) of the Faculty of Business, University of Moratuwa. Further, an article titled 'Sequential coherence: A novel determinant of open innovation performance' was published in the American Journal of Industrial \& Business Management. A paper titled Time Orientation \& Sequential Coherence as novel determinants of Open Innovation Performance was presented at the iPUMSE 2019 research conference organized by the University of Peradeniya.

\section{References}

Arashpour, M., Abbasi, B., Arashpour, M., Hosseini, M. R., \& Yang, R. (2017). Integrated management of on-site, coordination and off-site uncertainty: theorizing risk analysis within a hybrid project setting. International Journal of Project Management, 35(4), 647-655.

Arrow, K., (1971). Essays in the theory of risk bearing: Chicago, Markham.

Behnam, S., Cagliano, R., \& Grijalvo, M. (2018). How should firms reconcile their open innovation capabilities for incorporating external actors in innovations aimed at sustainable development?. Journal of Cleaner Production, 170, 950-965.

Bengtsson, L., Lakemond, N., Lazzarotti, V., Manzini, R., Pellegrini, L., \& Tell, F. (2015). Open to a select few? Matching partners and knowledge content for open innovation performance. Creativity and innovation management, 24(1), 72-86.

Bianchi, M., Croce, A., Dell'Era, C., Di Benedetto, C. A., \& Frattini, F. (2015). Organizing for inbound open innovation: How 
external consultants and a dedicated R\&D unit influence product innovation performance. Journal of Product Innovation Management.

Bogers, M., Zobel, A.K., Afuah, A., Almirall, E., Brunswicker, S., Dahlander, L., Frederiksen, L., Gawer, A., Gruber, M., Haefliger, S. and Hagedoorn, J.(2017). The open innovation research landscape: Established perspectives and emerging themes across different levels of analysis. Industry and Innovation, 24(1), 8-40.

Brunswicker, S., \& Vanhaverbeke, W. (2015). Open innovation in small and medium-sized enterprises (SMEs): External knowledge sourcing strategies and internal organizational facilitators. Journal of Small Business Management, 53(4), 1241-1263.

Caputo,M., Lambert, E., Cammarano, A., Michelino, F. (2016). Exploring the impact of open innovation on firm performance. Management Decisions. 54, 1788-1812.

Cheng, C. C., \& Huizingh, E. K. (2014). When is open innovation beneficial? The role of strategic orientation. Journal of Product Innovation Management, 31(6), 1235-1253.

Cheng, C. C., \& Shiu, E. C. (2015). The inconvenient truth of the relationship between open innovation activities and innovation performance. Management Decision, 53(3), 625647.

Chesbrough, H. (2003). The logic of open innovation: managing intellectual property. California Management Review, 45(3), $33-58$

Chesbrough, H. (2017). The Future of Open Innovation: IRI Medal Address The future of open innovation will be more extensive, more collaborative, and more engaged with a wider 
variety of participants. Research-Technology Management, 60(6), 29-35.

Cohen, W. M., \& Levinthal, D. A. (1990). Absorptive capacity: A new perspective on learning and innovation. Administrative science quarterly, 128-152.

Creswell, J. W. (2003). A framework for design. Research design: Qualitative, quantitative, and mixed methods approaches, 911.

Dahlander, L., \& Gann, D. M. (2010). How open is innovation?. Research policy, 39(6), 699-709.

De Mattos, C. A., Kissimoto, K. O., \& Laurindo, F. J. B. (2018). The role of information technology for building virtual environments to integrate crowdsourcing mechanisms into the open innovation process. Technological Forecasting and Social Change.

De Zubielqui, G. C., Jones, J., \& Lester, L. (2016). Knowledge inflows from market-and science-based actors, absorptive capacity, innovation and performance- A study of SMEs. International Journal of Innovation Management, 20(06), 1650055.

Duysters, G., \& Man, A. P. (2003). Transitory alliances: an instrument for surviving turbulent industries?. $R \& D$ Management, 33(1), 49-58.

Eisenhardt, K. M. (1989). Agency theory: An assessment and review. Academy of management review, 14(1), 57-74.

Enkel, E., Gassmann, O., \& Chesbrough, H. (2009). Open R\&D and open innovation: exploring the phenomenon. $R \& d$ Management, 39(4), 311-316.

Faems, D., De Visser, M., Andries, P., \& Van Looy, B. (2010). Technology alliance portfolios and financial performance: 
value-enhancing and cost-increasing effects of open innovation. Journal of Product Innovation Management, 27(6), 785-796.

Ferrary, M. (2011). Specialized organizations and ambidextrous clusters in the open innovation paradigm. European Management Journal, 29(3), 181-192.

Geels, F. W. (2004). From sectoral systems of innovation to sociotechnical systems: Insights about dynamics and change from sociology and institutional theory. Research policy, 33(6-7), 897-920.

Gkypali, A., Arvanitis, S., \& Tsekouras, K. (2018). Absorptive capacity, exporting activities, innovation openness and innovation performance: A SEM approach towards a unifying framework. Technological Forecasting and Social Change, 132, 143-155.

Godkin, L. (2010). The zone of inertia: absorptive capacity and organizational change. The Learning Organization, 17(3), 196-207.

Greco, M., Grimaldi, M., \& Cricelli, L. (2016). An analysis of the open innovation effect on firm performance. European Management Journal, 34(5), 501-516.

Greco, M., Locatelli, G., \& Lisi, S. (2017). Open innovation in the power \& energy sector: Bringing together government policies, companies' interests, and academic essence. Energy Policy, 104, 316-324.

Guan, J., \& Ma, N. (2003). Innovative capability and export performance of Chinese firms. Technovation, 23(9), 737-747.

Hargrave, T. J., \& Van de Ven, A. H. (2006). A collective action model of institutional innovation. Academy of management review, 31(4), 864-888. 
Haythornthwaite, C. (1996). Social network analysis: An approach and technique for the study of information exchange. Library \& information science research, 18(4), 323-342.

Hopkins, M. M., Tidd, J., Nightingale, P., \& Miller, R. (2011). Generative and degenerative interactions: positive and negative dynamics of open, user-centric innovation in technology and engineering consultancies. $R \& d$ Management, 41(1), 44-60.

Huang, H. C., Lai, M. C., Lin, L. H., \& Chen, C. T. (2013). Overcoming organizational inertia to strengthen business model innovation: An open innovation perspective. Journal of Organizational Change Management, 26(6), 977-1002.

Inauen, M., \& Schenker-Wicki, A. (2012). Fostering radical innovations with open innovation. European Journal of Innovation Management, 15(2), 212-231.

Kim, N., Kim, D. J., \& Lee, S. (2015). Antecedents of open innovation at the project level: empirical analysis of Korean firms. $R \& D$ Management, 45(5), 411-439.

Kogut, B., \& Zander, U. (1992). Knowledge of the firm, combinative capabilities, and the replication of technology. Organization science, 3(3), 383-397.

Lauritzen, G. D., \& Karafyllia, M. (2019). Perspective: leveraging open innovation through paradox. Journal of Product Innovation Management, 36(1), 107-121.

Laursen, K., \& Salter, A. (2006). Open for innovation: the role of openness in explaining innovation performance among UK manufacturing firms. Strategic management journal, 27(2), 131-150.

Lee, B., Cho, H. H., \& Shin, J. (2015). The relationship between inbound open innovation patents and financial performance: 
evidence from global information technology companies. Asian Journal of Technology Innovation, 23(3), 289-303.

Lopes, A.P.V.B.V. \& Carvalho, M.M.D. (2018). Evolution of the open innovation paradigm: Towards a contingency conceptual model. Technological Forecasting \& Social Change, 132, 284-298.

Lu, P., Yuan, S., \& Wu, J. (2017). The interaction effect between intra-organizational and inter-organizational control on the project performance of new product development in open innovation. International Journal of Project Management, 35(8), 1627-1638.

March, J. G. (1991). Exploration and exploitation in organizational learning. Organization science, 2(1), 71-87.

Moretti, F., \& Biancardi, D. (2018). Inbound open innovation and firm performance. Journal of Innovation \& Knowledge.

Munir, H., Linaker, J., Wnuk, K., Runeson, P., Regnell, B. (2018) Open innovation using open source tools: A case study at Sony Mobile. Empr Software Engineering, 23: 186-233.

Naqshbandi, M. M. (2016). Managerial ties and open innovation: examining the role of absorptive capacity. Management Decision, 54(9), 2256-2276.

Nooteboom, B., Van Haverbeke, W., Duysters, G., Gilsing, V., \& Van den Oord, A. (2007). Optimal cognitive distance and absorptive capacity. Research policy, 36(7), 1016-1034.

Pfeffer, J., \& Salancik, G. R. (2003). The external control of organizations: A resource dependence perspective. Stanford University Press.

Powell, W. W., Koput, K. W., \& Smith-Doerr, L. (1996). Interorganizational collaboration and the locus of innovation: 
Networks of learning in biotechnology. Administrative science quarterly, 116-145.

Pullen, A. J., Weerd-Nederhof, P. C., Groen, A. J., \& Fisscher, O. A. (2012). Open innovation in practice: goal complementarity and closed NPD networks to explain differences in innovation performance for SMEs in the medical devices sector. Journal of product innovation management, 29(6), 917-934.

Roper, S., \& Xia, H. (2014). Unpacking open innovation: Absorptive capacity, exploratory and exploitative openness and the growth of entrepreneurial biopharmaceutical firms. Enterprise Research Centre.

Teece, D. J., Pisano, G., \& Shuen, A. (1997). Dynamic capabilities and strategic management. Strategic management journal, 509-533.

Tichy, N. M., Tushman, M. L., \& Fombrun, C. (1979). Social network analysis for organizations. Academy of management review, 4(4), 507-519.

Von Krogh, G., Netland, T., \& Wörter, M. (2018). Winning With Open Process Innovation. MIT Sloan Management Review, 59(2), 53-56.

Williamson, O. E. (1975). Markets and hierarchies: analysis and antitrust implications: a study in the economics of internal organization.

Yapa, S. R., Senathiraja, R., \& Kauranen, I. (2018). Improving Innovation Performance by Convergence in Open Innovation: Evidence from Software Firms in Sri Lanka. Vidyodaya Journal of Management, 4(1).

Yapa, S.R., Senathiraja, R., Poesche, J. and Kauranen, I. (2019). Sequential Coherence: A Novel Determinant of Open Innovation Performance. American Journal of Industrial and 
Business Management, $\quad 9, \quad$ 1781-1799. https://doi.org/10.4236/ajibm.2019.99117

Yapa, S.R., Senathiraja, R., Poesche, J., \& Kauranen, I. (2020). Sequential Coherence as a Success Factor in Personal Selling. International Journal of Marketing Studies, 12(2). 